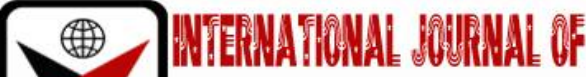

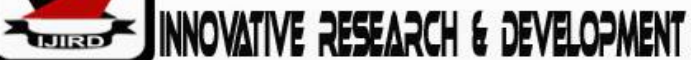

ISSN 2278 - 0211 (Online)

\section{Strategic Entrepreneurship and Business Sustainability: Moderating Effect of Level of Education}

Tijani, o. O.
Ph.D. Student, Department of Business Administration and Marketing
Babcock University, Ilishan-Remo, Ogun State, Nigeria
Egwuonwu, T. K.
Senior Lecturer, Department of Business Administration and Marketing
Babcock University, Ilishan-Remo, Ogun State, Nigeria
Akinlabi, H. B.
Lecturer, Department of Business Administration and Marketing
Babcock University, Ilishan-Remo, Ogun State, Nigeria

\begin{abstract}
:
Although liberal evidence has shown that strategic entrepreneurship activities of an employee positively impacts on organizational outcomes, nevertheless, research on how employees' level of education affect employee outcomes is scarce. This study examined strategic entrepreneurship and business sustainability using level of education as a moderator. The study adopted cross-sectional research design and primary source of data collection was utilised. The validity of the questionnaire was established through the construct, content, and face validity while internal consistency ascertained the reliability. Three textile manufacturing companies in Lagos State with a population of 253 senior staffs were utilized. Total enumeration was used; hence, 253 copies of the questionnaire were administered but only 237 copies were retrieved. Process analysis of regression was used as the method of data analysis. Findings indicated that level of education ( $\beta=-0.020, t=0.385, p=0.701, p>0.05)$ has a negative and statistically insignificant moderating effect on the relationship between strategic entrepreneurship and business sustainability of textile manufacturing firms in Lagos State, Nigeria. The study recommended that while the practice of strategic entrepreneurship is germane in textile manufacturing firms, organizations should not rely on the level of education of employees as it may not yield positive result in the sustenance of a business.
\end{abstract}

Keywords: Business sustainability, level of education, strategic entrepreneurship

\section{Introduction}

The sustainability exhibited by firms in technologically advanced countries could be attributable to the innovativeness of the entrepreneurs, ability to take risks, doggedness, and adaptability to changes inherent in their dynamic capabilities, and flexibility exhibited. Hence, the persistent desire for enterprise to ensure that their businesses survive and achieve sustainability is an impetus for strategic entrepreneurship considerations. Business sustainability as adopted by many organisations from small size to large size in different sectors of economies has resulted to total cost savings, enriched sales growth, and other business benefits (Kim \& Lee, 2018). Similarly, Timmermans and Katainen (2018) asserted that business sustainability models show the way towards a sustainable economy through an effective workforce (Phan, 2016).

According to Phan (2016), workforce with higher level of education enable firms to improve in their performance as they will be able to work effectively, efficiently and are more loyal to their profession. In the same vein, Amarteifio and Agbeblewu (2018) opined that the performance of business enterprises is reliant on the level of education, competencies and skills of its employees. As such, workers are becoming more educated, and enterprises are casting about to procure, maintain, and absorb knowledgeable workers to develop and sustain their business. Moreover, Dogan (2015); Paek and Lee (2017) asserted that for a firm to ensure it sustenance, strategic entrepreneurship should be institutionalized at individual-level perceptions and corporate opportunities in the form of firm-level strategies which enhances growth. In the same vein, Ukenna, Makinde, Akinlabi, and Asikhia (2019) asserted that strategic entrepreneurship involves organizational efforts to utilize opportunities and create wealth which ensures the firm's sustainability. 
Nigeria has been ranked low in textile sector performance by the Country Sustainability Ranking of 2019 with a score 3.0 out of 10.0 in the world's most sustainable country (Schieler, 2019). In line with this, Chukwu, Liman, Enudu, and Ehiaghe (2015); Murtala, Ramatu, Yusuf, and Gold (2018); Okeowo, (2017) identified low sustainability of the textile sector as being attributable to poor leadership, weak educational competencies, problem of inputs supply, demand, and price competitiveness of the Nigerian textile sector, lack of supportive infrastructure, smuggling and high cost of production which have sent many textile firms in Nigeria into catalepsy. A review of Nigerian manufacturers by the United Nations Industrial Development Organisation have shown that most enterprises in the nation scarcely get electric power as long as three days in a week, a development that seriously constrains production (Murtala et al., 2018) and thwarts the sustainability of the firm.

Furthermore, there are less than 25 textile production factories working in Nigeria as at 2018, down from 250 during the 80s and a large number of these 25 plants are delivering under capacity due to the inability to sustain themselves (Manufacturers Association of Nigeria, 2018). Similarly, the Central Bank of Nigeria (2019) has attributed the low sustainability of Nigerian textile firms to the low innovativeness, inflexible and poor capabilities which are among the factors combating the sector. Further confronted with rising cost of running operations and improper management the textile sector finds it difficult to sustain itself and its economic performance is meagre. In addition, MAN (2018) also attributed the absence of sustainability in the sector to the ineffective and inefficient utilization of resources resulting to low economic benefits and inability to aid national development. A study by International Labor Organization [ILO] (2014) shows that the lack of post-secondary education in Nigeria economies left the majority of young men and women stuck in susceptible and informal employment.

Moreover, Olumzy (2017) posited that the low level, quality and standard of education in Nigeria has beheld a symmetrical drop in the past two decades and this unfortunate development has made Nigeria the prominent country of origin of students from Africa migrating to other parts of the world in quest of quality education. Despite the Nigerian government's formulation of different policies to address some challenges facing the textile sector and enhance the sustainability of textile firms, the policies are yet to achieve the purposes of their formulation (National Union of Textile, Garment and Tailoring Workers of Nigeria [NUTGTWN], 2015) as the sector's performance has declined.

Several studies were carried out on level of education with other variables such as firm performance, market structure among others in various sectors (Amarteifio \& Agbeblewu, 2018; Chiliya \& Roberts-Lombard, 2012; Kamau, 2013; Muthoni, 2013; Phan, 2016; Sagire, 2017). In light of these studies, Phan (2016) concluded that the board of directors' educational level influences firm performance. In the same vein, Amarteifio and Agbeblewu (2017) found positive significant relationship of level of education on business experience and small and medium enterprise performance. Similarly, a study by Sagire (2017) revealed that level of education and age of the firm have a positive effect on performance. Murphy, Rabelo, Silagi, Mansur, and Schochat (2016) discovered that educational level has a significant effect on performance. Moreover, studies that employed level of education as a moderating factor between strategic entrepreneurship and business sustainability is limited in the Nigeria textile sector. It is on this premise that this paper investigated the moderating effect of level of education on the relationship between strategic entrepreneurship and business sustainability of textile manufacturing firms in Lagos State. The work is structured as a literature review after the introduction, methodology, findings presentation, conclusion, and recommendation.

\section{Literature Review}

This consists of the reviews of previous studies on the independent variable, the dependent variable and the moderator. This was done conceptually, empirically and theoretically to apprehend the interactions among the variables.

\subsection{Business Sustainability}

Ford (2012) defines business sustainability as the ability to meet the needs of present customers while taking into account the needs of future generations. Here, business sustainability is vital as it ensures satisfaction of all customers. Similarly, Wales (2013) posited that business sustainability is the principle of improving the societal, environmental and economic systems within which a business operates. Sulaeman, Tisnawatisule, Hilmiana, and Cahyandito (2018) further asserted that business sustainability is the goal of every business in the long run which is achieved through the balance of the performance of economic, social and environmental dimensions referred to as the 'Triple Bottom Line'. Studies claimed that business sustainability gives advantages and opportunities such as the prospect for opening new markets, refining competitive position, breeding greater consumer and shareholder approval, augmenting company image, improving employee impetus, and cost reduction (Chen, Feldmann, \& Tang, 2015; Sukitsch, Engert, \& Baumgartner, 2015). The main pillars of business sustainability as noted by Wales (2013) are societal, environmental as well as economic sustainability. The study slings towards the economic sustainability to achieve its objective. Thus, this study utilized profitability, competitive advantage, market share, sales growth and revenue growth as the dimensions of business sustainability.

Greuning (2009) sees profitability as gage of how a company's earnings brims are associated with sales, average capital and own average capital. On the other hand, David (2016) asserted that competitive advantage is the enlarged rate of desirability a firm offers compared to rivals from customers' perspectives and it is the capability of an organisation to stay ahead of current or prospective competition. Market share of a business is the amount of buyers and sellers of the organisation in a specified market (Micheal, 2016). According to Pinem and Dwi (2014), sales growth shows the percentage escalation in sales of the contemporary year compared to the preceding year. Saridakis, Lai, Mohammed, and Hansen (2018) defined revenue growth as an upsurge in the total sum acquired from the sale of a stock or services to customers. Thus, this study sees business sustainability as the ability of a firm to maintain and improve its competitive 
advantage, firm profitability, market share, sales growth and revenue growth in order to achieve its predetermined goals, objectives and enhance performance.

\subsection{Strategic Entrepreneurship}

Strategic entrepreneurship is the environmental, organisational and individual resources; procedures involving organisation of the resources; climax to value creation, competitive advantage, wealth development and knowledge spillover aids, requiring need for suitable plans (Mazzei, David, \& Christopher, 2017). Mazzei (2018) defined strategic entrepreneurship as managerially substantial innovations within existing firms that encompass the combination/incorporation of opportunity- and advantage-seeking conducts. Innovation, strategic leadership, strategic flexibility, dynamic capabilities, adaptability and risk taking are adopted in this study as the scope of strategic entrepreneurship.

Tuan, Nhan, Giang, and Ngoc (2018) define innovation as the enactment of a novel or meaningfully enhanced product (goods or service), process, a new marketing practise or a new organisational technique in business practices, workplace business or external. On the other hand, strategic leadership is about leadership deeds at upper levels of a firm (Onu, Akinlabi, \& Egbuta, 2018). Risk taking involves taking bold steps, by entering into the uncertain business environment and borrowing heavily (Eze, 2018). Dynamic capabilities is espoused as a firm is exhibition of her character of familiarizing, refurbishing, reconfiguring and reinventing resources and core proficiencies to respond to fluctuating business environs (Akram \& Hilman, 2018). Ahmadi and Osman (2017) viewed strategic flexibility as a dynamic capability of having various strategic actions and making shifts in strategic actions, which requires to be complemented by managerial activity of making shifts in resource allocation to work properly. Busch (2011) stressed that adaptation is a procedure of organisational change that must be practised in the perspective of a connexion process of human and organisation enhancement over time.

\subsection{Level of Education}

Education is indispensable for nationwide development and a flourishing society. Education is one of the rudimentary prerequisites for human improvement and to escape from poverty (Sivakumar \& Sarvalingam, 2010). Education involves evolving conducts, abilities, and qualities applied individually and/or communally to help people to generate, manage with, and relish change and novelty in the society (Amadi-Echendu, Phillips, Chodokufa, \& Visser, 2016; Izedonmi \& Okafor, 2010). In addition, Longanecker and Blanco (2013) defined education as who and how learners are imparted rather than by what students learn. Their explanation climaxes both the perceptions of educational staff and managers. This study views level of education as the educational attainment that a person has accomplished progressing from the elementary level to the higher and complex level.

\subsection{Strategic Entrepreneurship, Business Sustainability and Level of Education}

Empirically, evidence on several studies revealed that level of education has a positive effect on variables such as firm performance, market structure among others (Amarteifio \& Agbeblewu, 2017; Chiliya \& Roberts-Lombard, 2012; Kamau, 2013; Muthoni, 2013). The work of Magoutas, Papadogonas and Sfakianakis (2012) found that education positively influences firm growth. Moreover, the study of Phan (2016) was a leeway of Magoutas et al (2012) which concluded that firm performance is influenced by the board of directors' education. Also, results showed that education has been a pre-requisite to employees' competencies in an organization. In the same vein, Chiliya and Roberts-Lombard (2012) revealed that level of education is positively related to profitability. The scholarly consensus amid past studies was confirmed by Sagire (2017) which showed that educational level and age of the firm have a positive effect on performance.

The study of Ng and Feldman (2009) found positive relationship between education and task performance of employees. In the same vein, Kotur and Anbazhagan (2014) was able to ascertain that level of education enhances employee performance. This attest that the level of employee's formal education ensures the optimum performances of the employees due to the higher educational qualification. Similarly, the study of Fajar (2015) corroborated the findings of Kotur and Anbazhagan (2014) that although formal education and informal education significantly influences workers performance in an organization, firms should be supportive by ensuring that workers are being trained and educated periodically so as to acquire more learning. In addition, the work of Amarteifio and Agbeblewu (2017) confirmed the study of Kotur and Anbazhagan (2014) and found significant relationship.

Conversely, Khan, Ahmad, Iqbal, and Haider (2014) revealed mixed results that informal education is positively correlated with performance of financial institution and that formal education has a negative correlation with financial institution performance. Similarly, Hung (2016) found no correlation between education firms' director and financial performance. Ishola, Adeleye, and Tanimola (2018) result demonstrated that bursary staff with professional qualification conveyed more occupation performance than non-certified staff. Bursary staff with greater tertiary education performed healthier in accounting task than those with lower qualification. The dearth of unanimity amid past studies were ascribed to the varied topographical constituency in which the study were piloted and the altered context of strategic entrepreneurship.

In consonance with the empirical findings from previous studies, the Schumpeter theory of entrepreneurship propounded by Joseph Schumpeter (1949) assumes that disequilibrium is created by entrepreneurs and thus, entrepreneurs are agents of creative destruction in a capitalistic economy system. Schumpeter did not share the view of Kirzner's alertness in entrepreneurship. This creative destruction is achieved or done through innovation that entrepreneurs bring to the market. This showed that innovation is the status of entrepreneurship (Mudiwa, 2017). This theory assumes that an entrepreneur is the person that creates a new business to produce a new product or to make an 
old product in a new way. Ukenna, Makinde, Akinlabi, and Asikhia (2019) averred that individuals possess mental and creative ability to convert innovative ideas to economically viable products or services that meet the demands of the people. However, Simpeh (2011) critiqued the theory that it rests all responsibility of innovation on an individual that Schumpeter referred to as 'great man' and this theory did not consider individuals that try to be innovative in their business activities but failed.

\section{Methodology}

This study utilized a quantitative method through the adoption of cross-sectional survey research design because it captures information based on data gathered in a specific point in time. The substantiation for the choice to use crosssectional survey is consistent with the study of Makinde and Agu (2018) that investigated strategic entrepreneurship and performance of small and medium scale enterprises in Aba metropolis; Haddawee (2018) exploration of the impact of strategic foresight on strategic entrepreneurship. This study was conducted in Lagos State Nigeria since the state is Nigeria's economic centre. According to MAN (2018), due to the low sustainability of the textile sector and their underperformance (below 20\%), out of the fifteen textile firms in Lagos State, there are only three surviving manufacturing firms, namely, Wollen and Synthetic Textile Ltd, Nichemtex Textile Ltd and Sunflag Textile Ltd in Lagos State with a population of 253 senior staff. Due to the low population, the study adopted total enumeration of the senior staff as the sample size of the study. The senior staff were selected because they hold strategic positions in the firm and they are involved in both strategic and tactical decision making.

Primary source of data collection was utilized with the aid of a structured questionnaire which is divided into four sections. Section A addresses the demographic, section B, C and D tackle question items on strategic entrepreneurship, business sustainability and level of education, respectively. The items in the questionnaire were adapted from past studies because they have been used previously in different countries (Augier \& Teece, 2014; Ghorban-Bakhsh \& GholipourKanani, 2018; Norzailan, Yusof, \& Othman, 2016; Olajide, 2015; Ukenna et al., 2019) while questions on level of education are self-structured.

Pilot test was conducted on the questionnaire along with validity and the reliability test. Content, criterion and construct validity were established (Comrey, 1973) to determine the reliability of the instrument. Whereas the face content or face validity (scale's validity) was used to measure how well the content of the research measurement instrument measures what it is designed to measure. The content validity was addressed through the review of literature; adapting instruments used in previous research that has been critically reviewed and validated, and self-developed through conceptual review. While the criterion validity was used to measure the ability of the research instrument to predict future outcomes. Validity test was carried out using Kaiser-Meyer-Olkin (KMO) test of SPSS. The result revealed ( $\alpha$ ) $=0.78$ (with the lowest being 0.615 ; and the highest 0.801 ). The structured questionnaire was considered reliable since the results of the pre-test result as depicted by the Cronbach's alpha from internal consistency test was greater than 0.70 and closer to 1.0 (Nunnally, 1978). The study employed process analysis for the data analysis.

\subsection{Model Specification}

$\mathrm{Y}=\mathrm{f}(\mathrm{XZ})$

Where: Y = Business Sustainability (BS);

$\mathrm{X}=$ Strategic Entrepreneurship (SE);

$\mathrm{Z}=$ Level of Education

The functional relationship of the model is presented as:

$\mathrm{BS}=\mathrm{f}(\mathrm{SE} L E)$

Thus,

$B S=a+\beta_{i} S E_{i}+\beta_{2} L E_{i}+\beta_{3} S E^{*} L E_{i+} \mu_{i}$

$\mathrm{a}=$ constant of the equation or constant term i.e. the level of the level of business sustainability when strategic entrepreneurship is not available or zero.

$\beta_{1}-\beta_{3}=$ Parameters to be estimated

$\mathrm{SE}=$ Strategic Entrepreneurship,

$L E=$ Level of Education,

SE*LE = Interaction of strategic entrepreneurship and level of education

$\mu=$ error or stochastic term i.e. the value of other extraneous variables not included in the model.

The paper was carried out with strict accordance with the rules and guidelines of research. In order to ensure anonymity of the respondents, efforts are put in place to ensure the confidentiality of data collected; optimum honesty was ensured in process the data, result reporting, method and procedure. The study also ensured that no false data were included in the data collected and that the process of presenting and interpreting the data is free from bias. The questionnaire copies were filled voluntarily and willing by the respondents.

\section{Results and Discussions}

A total of 253 copies of questionnaire were distributed. A total of 237 copies of questionnaire were properly filled and returned. The inferential statistics for the study are presented below. The study utilized SPSS process analysis (version 23) to determine the moderating effect of level of education on the relationship between strategic entrepreneurship and business sustainability of textile manufacturing firms in Lagos State, Nigeria. The moderating variable was level of education, the independent variable was strategic entrepreneurship (innovativeness, strategic leadership, risk taking, dynamic capabilities, strategic flexibility and adaptability) and the dependent variable was 
business sustainability (firm profitability, competitive advantage, sales growth, market share and revenue growth). The results of the process analysis are shown in Table 1.

\begin{tabular}{|c|c|c|c|c|c|c|c|}
\hline & $\boldsymbol{R}$ & $\boldsymbol{R}^{2}$ & StdE & F & df1 & df2 & $\boldsymbol{P}$ \\
\hline & 0.664 & 0.441 & 0.266 & 61.156 & 3 & 233 & 0.000 \\
\hline
\end{tabular}

Table 1: Model Summary of Regression Analysis for Moderating Effect of Level of Education between Strategic

Entrepreneurship And Business Sustainability of Textile Manufacturing Firms in Lagos State, Nigeria

Outcome Variable: Business Sustainability

Source: Field Survey (2019)

\begin{tabular}{|c|c|c|c|c|c|c|}
\hline Model & Beta & SE & T & $\boldsymbol{P}$ & LLCI & ULCI \\
\hline Constant & 4.049 & 0.034 & 120.711 & 0.000 & 3.982 & 4.115 \\
\hline Strategic Entrepreneurship & 0.851 & 0.064 & 13.324 & 0.000 & 0.725 & 0.977 \\
\hline Level of Education & 0.045 & 0.028 & 1.622 & 0.106 & -0.010 & 0.100 \\
\hline $\begin{array}{c}\text { Strategic Entrepreneurship* } \\
\text { Level of Education }\end{array}$ & -0.020 & 0.051 & -0.385 & 0.701 & -0.121 & 0.082 \\
\hline
\end{tabular}

Table 2: Model of Regression Analysis

Source: Field Survey (2019)

Outcome Variable: Business Sustainability

\begin{tabular}{|c|c|c|c|c|c|}
\hline & $\mathbf{R}^{2} \Delta$ & $\mathbf{F}$ & $\mathbf{d f 1}$ & $\mathbf{d f 2}$ & $\mathbf{P}$ \\
\hline $\mathrm{X}^{*} \mathrm{Y}$ & 0.000 & 0.148 & 1 & 233 & 0.701 \\
\hline \multicolumn{6}{|c|}{ Table 3: Indirect Effect(s) of X on $Y$} \\
Source: Field Survey (2019)
\end{tabular}

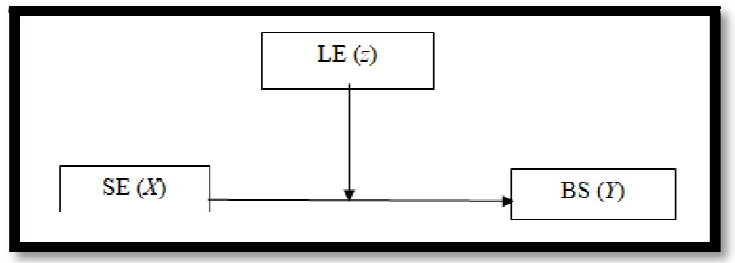

Figure 1: Process Analysis (model 1)

Process analysis using model 1 of the SPSS process add-on was used as depicted in figure 1 as the method of data analysis. The analysis revealed that the introduction of the moderator (level of education) in table 1 significantly improved the effect of level of education on the relationship between strategic entrepreneurship and business sustainability of textile manufacturing companies in Lagos State, Nigeria $\left(R^{2}=0.441, \mathrm{p}<0.05\right)$. Strategic entrepreneurship and level of education explained $44.1 \%$ of the variation in business sustainability of textile manufacturing firms in Lagos State, Nigeria. Furthermore, the $\mathrm{F}$ value in Table 1 is statistically significant $\left(F_{(3,233)}=61.156, p=0.000\right)$ revealed that the influence of the independent variable and the moderator were significant in the model.

The results of the analysis in Table 2 revealed a statistically significant coefficients for strategic entrepreneurship $(\beta=0.851, \mathrm{t}=13.324, p<0.05)$ indicating that there is a linear dependence of business sustainability on strategic entrepreneurship of textile manufacturing firms in Lagos State, Nigeria. This result implies that for every unit increase in strategic entrepreneurship sub-variables, business sustainability would increase by 0.851 units of textile manufacturing companies in Lagos State, Nigeria. Furthermore, level of education $(\beta=0.045, t=1.622, p>0.05)$ was statistically insignificant. The result indicates that level of education has a positive and insignificant effect on business sustainability of textile manufacturing firms in Lagos State, Nigeria. This shows that for every unit increase in level of education, business sustainability would increase by 0.045 units in the textile manufacturing firms in Lagos State, Nigeria.

The introduction of the interaction term (strategic entrepreneurship* level of education) revealed a negative and insignificant effect $(\beta=-0.020, \mathrm{t}=0.385, p=0.701(p>0.05)$. This implies that for every unit change in interaction term, business sustainability would decrease by 0.020 units in the textile manufacturing firms in Lagos State, Nigeria. The result of the analysis revealed that level of education has a negative and statistically insignificant moderating effect on the relationship between strategic entrepreneurship and business sustainability of textile manufacturing companies in Lagos State, Nigeria.

Also, the $R^{2} \Delta$ in Table 3 as a result of the introduction of the interaction term is 0.000 at $p=0.701(p>0.05)$ which indicates that the interaction term (strategic entrepreneurship* level of education) accounts for no (0.0\%) variation in business sustainability and is statistically insignificant. The established regression equation from the results is stated as follows: 


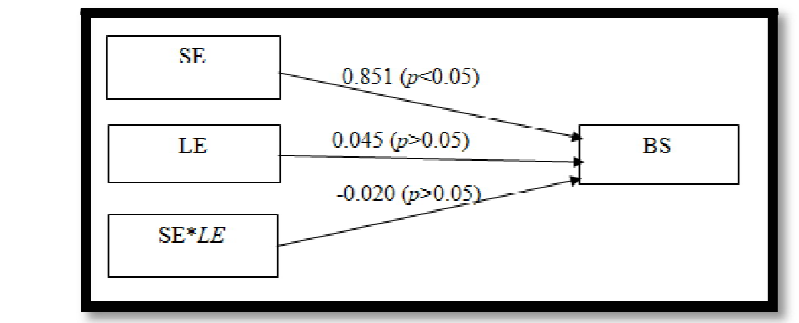

Figure 2: Regression Model

$B S=4.049+0.851 S E+0.045 L E-0.020 S E^{*} L E$ eqn. $i$

Based on these findings, the result concluded that level of education has no significant moderating effect on the relationship between strategic entrepreneurship and business sustainability of textile manufacturing firms in Lagos State, Nigeria.

\section{Discussion of Findings}

The results of the process analysis for the moderating effect of level of education on the relationship between strategic entrepreneurship and business sustainability of textile manufacturing firms in Lagos State, Nigeria showed that level of education has no significant moderating effect on the relationship between strategic entrepreneurship and business sustainability of textile manufacturing firms in Lagos State, Nigeria. The result supports the findings of Khan, Ahmad, Iqbal, and Haider (2014) that formal education is not a prerequisite for improved firm performance. In addition, an individual's educational level does not affect their output when appropriate resources and skills are extant.

Across the globe, diverse scholar have conceptually negated the findings of this paper (Adegbuyi, Fadeyi, Kehinde, \& Adegbuyi, 2016; Glaeser, 2011; Longanecker \& Blanco, 2013) that level of education has no significant moderating effect on the relationship between strategic entrepreneurship and business sustainability of textile manufacturing firms in Lagos State, Nigeria. In line with this, Sivakumar and Sarvalingam (2010) positioned that education is indispensable for nationwide development and a flourishing society. Supporting this, Amadi-Echendu, Phillips, Chodokufa, and Visser (2016) concurred that the ability of individuals to generate, manage with, and relish change and novelty in the society enables them to create innovative ideas which is important for the sustenance of the economy.

Similarly, the discoveries of Hung (2016) also collaborated with Khan et al (2014) that not every educated senior management staff contributes to the performance of an organization. Level of education is neither a criterion for the sustainability of a business nor for an individual to be a strategic entrepreneur. Congruently, the studies of $\mathrm{He},(2015)$ and Olajide (2018) confirmed that high level of formal education has no significant impact of the growth of an organization when working in an appropriate environment with sufficient assets. In addition, the absence of education or low level of education of an individual does not depreciate their performance as far as the firm is supportive by warranting that its workforces are been proficient and educated sporadically so as to acquire more learning and ensure exponentially growth and sustenance of the firm.

However, the study of Magoutas, Papadogonas, and Sfakianakis (2012) that well educated employees positively influence the performance of a firm as well as the growth of the firm negates the findings of this study. Similarly, Chiliya and Roberts-Lombard (2012) also affirmed that employees which possess both high level of education and long years of experience have a positive impact on the profitability and sustenance of an enterprise. Conversely, employees with poor educational background and low learning incentives by the firm results in some deleterious consequences. Moreover, the study of Phan (2016) was a leeway of Magoutas et al (2012) which also corresponded that individuals with higher level of education hold strategic positions in an organization and make both strategic and tactical decisions to enhance the performance of the firms. Sagire (2017) established that high educational level has impact on employees, their work outcomes and the firm performance as a whole. Their (Phan, 2016; Sagire, 2017) findings is also consistent with the submissions of some earlier scholars that level of education enhances the performance of an organization (Ng \& Feldman, 2009; Kotur \& Anbazhagan, 2014).

This implies that the level of education attained by the firms is being used on the operational activities of the firms towards achieving the firms' mission and vision. It is certain that the firms do embark on educational programmes in order to enhance the capabilities of the employees. Also, learning through the environmental changes influences the level of education of the firms' which has reflected in the ways the firms' are being sustained (Höglund, Holmgren, \& Mårtensson, 2013; Mazzei, 2018; Mazzei, David, \& Christopher, 2017). The results of this study also negates the findings of Amarteifio and Agbeblewu (2017); Kamau (2013); Muthoni 2013) which revealed that extraordinary educational level enhances the sustainability of a business and ensures the growth of the firm.

It is observed that majority of the past studies is been negated by the findings of this study that level of education moderates the relationship between strategic entrepreneurship and business sustainability and fewer studies had contrary results to the moderating role of level of education on the relationship between strategic entrepreneurship and business sustainability. Nevertheless, the findings of this study was supported by the Schumpeter theory of entrepreneurship (Schumpeter, 1949) that entrepreneurs are agents of inventive annihilation in a capitalistic economy system which is accomplished or done through innovation that entrepreneurs convey to the market and not by their level of education. This showed that innovation as the status of entrepreneurship (Mudiwa, 2017) is not dependent on the level of education of the individual but on the creative skills and competences of the entrepreneur. Therefore, a link exists between the need for individuals that possess mental and creative ability to convert innovative ideas to economically 
viable products or services that meet the demands of the people and ensure the sustainability of a business (Ukenna, Makinde, Akinlabi, \& Asikhia, 2019).

\section{Conclusion and Recommendation}

Sustainability is one of the objectives of every business or organization in the $21^{\text {st }}$ century. This paper reviewed various perspectives of past scholars conceptually, theoretically and empirically. The study established that strategic entrepreneurship positively influenced business sustainability and there is no moderating effect of level of education on the relationship between strategic entrepreneurship and business sustainability. Thus, the study recommended that textile manufacturing firms should encourage the employees to acquire more skills, be innovative, risk takers and learn how to adapt to the turbulent business environment. Also, strategic entrepreneurship should continue to be practiced by the textile manufacturing firms in Lagos State, Nigeria. Future researchers should replicate this study in nonmanufacturing textile firms to widen the shrewdness on the effect of level of education. Furthermore, future research could employ longitudinal survey research design to capture the dynamics of strategic entrepreneurship practices and firm performance.

\section{References}

i. Adegbuyi, A. A., Fadeyi, O. I., Kehinde, J. O., \& Adegbuyi, O. A. (2016). Nigerian socio-economic development: The roles and challenges of small and medium enterprises development agency of Nigeria (SMEDAN). A descriptive Perspective. Proceedings of the 3rd International Conference African Developmental Issues (CU-ICADI) 217-221.

ii. Ahmadi, M., \& Osman, M. H. (2017). Influence of context on strategic flexibility- A critical review. International Journal of Innovation and Business Strategy, 8(2), 17-29.

iii. Akram, S., \& Hilman, H. (2018). Effect of knowledge management activities and dynamic capabilities on employee performance in the banking sector: Empirical evidence from Pakistan. Studies in Business and Economics, 13(2), 41-60.

iv. Amadi-Echendu, A. P., Phillips, M., Chodokufa, K., \& Visser, T. (2016). Entrepreneurial education in a tertiary context: A perspective of the University of South Africa. The International Review of Research in Open and Distributed Learning, 17(4), 22-36.

v. Amarteifio, E., \& Agbeblewu, S. (2017). Level of education, business experience and small and medium enterprise performance in the Accra metropolis of Ghana. International Journal of Multidisciplinary and Current Research, 5 , 1460-1474.

vi. Association of African Universities. (2009). 12th General Conference 4th-8th May 2009 International Conference Centre, Abuja, Nigeria, 'Sustainable Development in Africa: The Role of Higher Education' Conference Report.

vii. Augier, M., \& Teece, D. J. (2014). Dynamic capabilities and the role of managers in business strategy and economic performance. Organization Science, 20(2), 410-421.

viii. Bonini, S., \& Bove, A. T. (2014). Sustainability's strategic worth. McKinsey Global Survey results.Retrievedfrom:http://www.mckinsey.com/insights/sustainability/sustainabilitys_strategic_worth_mckins ey_global_survey_results

ix. Busch, T. (2011). Organizational adaptation to disruptions in the natural environment: The case of climate change. Scandinavian Journal of Management, 102-119.

x. CBN (2019). CBN Inaugurates Committee to Revive Textile Industry. Retrieved from https://www.thisdaylive.com/index.php/2019/05/17/cbn-inaugurates-committee-to-revive-textile-industry/

xi. Chen, L., Feldmann, A., \& Tang, O. (2015). The relationship between disclosures of corporate social performance and financial performance: Evidences from GRI reports in manufacturing industry. International Journal of Production Economics, 170, 445-456.

xii. Chiliya, N., \& Roberts-Lombard, M. (2012). Impact of level of education and experience on profitability of small grocery shops in South Africa. International. Journal of Business Management and Economic Research, 3(1), 462470.

xiii. Chukwu, B., Liman, N., Enudu, T., \& Ehiaghe, A. (2015). The effect of economic recession in textile manufacturing industries in Nigeria. Asian Journal of Business Management, 7(3), 43-54.

xiv. Comrey, A. L. (1973). A First Course in Factor Analysis. New York, NY: Academic Press.

XV. David, F. (2016). Strategic Management (12 th Ed). Tehran: Cultural researches publication

xvi. Dogan, L. (2015). The intersection of entrepreneurship and strategic management: Strategic entrepreneurship. Social and Behavioral Sciences, 195, 1288 - 1294.

xvii. Eze, B. U. (2018). Corporate entrepreneurship and manufacturing firms' performance. Emerging Markets Journal, $8(1), 11-18$.

xviii. Fajar, K. S. (2015). Effect of education and training to performance mediated career development inspectorate city employees. The International Journal of Engineering and Science, 4(3), 28-36.

xix. Ford (2012). http://corporate.ford.com/doc/corpgov_sustainability_committee_charter.pdf

xx. Ghorban-Bakhsh, R., \& Gholipour-Kanani, Y. (2018). Investigating the impact of strategic flexibility on organizational innovation. International Review of Management and Marketing, 8(3), 1-5.

xxi. Glaeser, E. L. (2011). Cities, Skills, and Regional Change. Available at SSRN: https://ssrn. com/abstract =1805086

xxii. Greuning, H. (2009). Banking and risk environment. Asia: John Wiley and Son.

xxiii. Haddawee, A. H. (2018). The impact of strategic foresight on strategic entrepreneurship. The International Journal of Social Sciences and Humanities Invention 5(5), 4687-4699. 
xxiv. He, L. J. (2015). Auditor industry specialization, audit experience and accounting restatement. International Business Management, 9, 1686-1697.

xxv. Höglund, L., Holmgren, M., \& Mårtensson, M. (2013). Strategic entrepreneurship practices at robotdalen- A balancing act or not? Retrieved from https://www.researchgate.net/publication/275886671.

xxvi. Hung, P. (2016). Board of director education and firm performance: A dynamic approach. Master's Thesis, Aalto University.

xxvii. ILO (2014). Retrieved from https://www.un.org/youthenvoy/2014/12/lack-higher-education-leaves-millionsyouth-decent-work-developing-countries/

xxviii. Ishola, A. A., Adeleye, S. T., \& Tanimola, F. A. (2018). Impact of educational, professional qualification and years of experience on accountants' job performance. Journal of Accounting and Financial Management, 4(1), 32-46 2018.

xxix. Izedonmi, P., \& Okafor, C (2010). The effect of entrepreneurship education on students' entrepreneurial intentions. Global Journal of Management and Business Research, 10(6), 49-60.

xxx. Kamau, L. M. (2013). Relationship between family background and academic performance of secondary schools students: A case of Siakago Division, Mbeere North District, Kenya. M.A., University of Nairobi.

xxxi. Khan, N., Ahmad, N., Iqbal, N., \& Haider, N. (2014). Relationship of training and education with employee performance in financial institutions. International Letters of Social and Humanistic Sciences, 41, 150-156.

xxxii. Kim, K., \& Lee, S. (2018). Does sustainability affect corporate performance and economic development? Evidence from the Asia-Pacific Region and North America. Sustainability, 1, 1-14.

xxxiii. Kotur, B. R., \& Anbazhagan, S. (2014). Education and work-experience - Influence on the performance. Journal of Business and Management, 16(5), 104-110.

xxxiv. Longanecker, D. A., \& Blanco, C. D. (2013). Public policy implications of changing student attendance patterns. New Directions for Higher Education, 121, 51-68.

xxxv. Magoutas, A. I., Papadogonas, T. A., \& Sfakianakis, G. (2012). Market Structure, Education and growth. International Journal of Business and Social Science, 3(12), 88-96.

xxxvi. Mahajan, R., \& Bose, M. (2018). Business sustainability: Exploring the meaning and significance. IMI Konnect 7(2) 8-13.

xxxvii. Makinde, O. G., \& Agu, C. U. (2018). Strategic entrepreneurship and performance of small and medium scale enterprises in Aba Metropolis. Archives of Business Research, 6(9), 49-69.

xxxviii. Manufacturers Association of Nigeria. (2018). Manufacturers Association of Nigeria Situation Report. MAN.

xxxix. Mazzei, M. J. (2018). Strategic entrepreneurship content, process, context, and outcomes. International Entrepreneurship and Management Journal, 2, 1-14.

xl. Mazzei, M. J., David, J. K., \& Christopher, L. S. (2017). Understanding strategic entrepreneurship: A 'theoretical toolbox' approach. International Entrepreneurship and Management Journal, 13(2), 631-663.

xli. Micheal, A. (2016). Consumer buying behavior and market share of distributing firms in Lagos State. M.Sc. Thesis, Lagos State University, Ojo.

xlii. Mudiwa, B. (2017). Theories of smallholder agribusiness entrepreneurship in the African context: A critical review. International Journal of Arts and Humanities, 6(1), 221-236.

xliii. Murtala, M., Ramatu, B., Yusuf, H. A., \& Gold, K. L. (2018). Nigerian textile sector: Evidence of policy neglect. Sarjana, 33(1), 40-56.

xliv. Muthoni, K. L. (2013). Relationship between family background and academic performance of secondary schools students: A case of Siakago Division, Mbeere North District, Kenya. M.A., University of Nairobi.

xlv. National Bureau of Statistics [NBS] (2019). Retrieved from https://nigerianstat.gov.ng/elibrary

xlvi. National Union of Textile Garment and Tailoring Workers of Nigeria. (2015). Textile Industries. Retrieved from http:// www.nutgtwn.com

xlvii. Ng, T. W. H., \& Feldman, D. C. (2009). How broadly does education contribute to job performance? Personnel Psychology, 62, 89-134.

xlviii. Nigerian Textile Manufacturing Association. (2018). Nigerian Textile Manufacturers Association Competitiveness Assessment on Several Performance Indicators, Lagos.

xlix. Norzailan, Z., Yusof, S., \& Othman, R. (2016). Developing strategic leadership competencies. Journal of Advanced Management Science, 4(1), 36-51.

1. Nunnally, J. C. (1978). Psychometric Theory (2nd Ed). New York: Mcgraw-Hill.

li. Okeowo, F. O. (2017). Trade liberalization and performance of the Nigerian textile sector (1986 - 2015$)$. Ph.D. Thesis, Babcock University.

lii. Olajide, O. T. (2018). Entrepreneurship skill development, government support and growth of SMEs in Nigeria. Journal of Entrepreneurship and Innovation, 10, 181-196.

liii. Olajide, R. A. (2015). Revenue generation as a major source of income for the state government: An empirical analysis of two parastatals. International Journal of Economics, Commerce and Management, 3(6), 1346-1366.

liv. Olumzy (2017). Retrieved from https://steemit.com/nigeria/@olumzy/the-problems-and-solutions-toeducational-standard-in-nigeria

lv. Onu, C. A., Akinlabi, B. H., \& Egbuta, O. (2018). Strategic leadership and organizational performance in Nigeria: An empirical investigation. European Journal of Business and Management, 10 (25), 76-85.

lvi. Paek, B., \& Lee, H. (2017). Strategic entrepreneurship and competitive advantage of established firms: evidence from the digital TV industry. International Entrepreneurial Management Journal, 1, 1-43. 
lvii. Phan, H. (2016). Board of director education and firm performance: A dynamic approach. Master's Thesis, Aalto University.

lviii. Pinem, D., \& Dwi, B. (2014). The analysis of company performance and sales growth to the dividend policy at the company go public in Indonesia stock exchange. International Journal of Business and Commerce, 5(6), $105-116$.

lix. Sagire, L. (2017). The impact of demographic and social factors on firm performance in Kenya. Journal of Business and Economic Development, 2(4), 255-26.

lx. Saridakis, G., Lai, Y., Mohammed, A. M., \& Hansen, J. M. (2018). Industry characteristics, stages of E-commerce communications, and entrepreneurs and SMEs revenue growth. Technological Forecasting and Social Change, 128, 56-66.

lxi. Schieler, M. (2019). RobecoSAM Country Sustainability Ranking. Retrieved from https://www.researchgate.net/publication/334050864_June_2019_Country_Sustainability_Ranking

lxii. Schumpeter, J. A. (1949). The Theory of Economic Development. Cambridge. Harvard University Press; pp. 74-86.

lxiii. Simpeh, K. N. (2011). Entrepreneurship theories and empirical research: A summary review of the literature. European Journal of Business and Management, 3(6), 1- 9.

lxiv. Sivakumar, M., \& Sarvalingam, A. (2010). Human deprivation index: A measure of multidimensional poverty. Retrieved from https://unhabitat.org/urban-themes/housing-slum-upgrading

lxv. Sukitsch, M., Engert, S., \& Baumgartner, R. J. (2015). The implementation of corporate sustainability in the European automotive industry: An analysis of sustainability reports. Sustainability 7(9), 11504-11531.

lxvi. Sulaeman, A., Tisnawatisule, E., Hilmiana, H., \& Cahyandito, M. F. (2018). Determining SMEs business sustainability: Human resources management for sustainability approach. 1st International Conference on Economics, Business, Entrepreneurship, and Finance (ICEBEF 2018). Advances in Economics, Business and Management Research, 65, 764-768.

lxvii. Timmermans, F., \& Katainen, J. (2018). Towards a sustainable Europe by 2030. European Union report.

lxviii. Tuan, N., Nhan, N., Giang, P., \& Ngoc, N. (2016). The effects of innovation on firm performance of supporting industries in Hanoi, Vietnam. Journal of Industrial Engineering and Management, 9(2), 413-431.

lxix. Ukenna, B. I., Makinde, G. O., Akinlabi, B. H., \& Asikhia, O. U. (2019). Strategic entrepreneurship and organizational performance of selected agricultural SMEs in Lagos, Ogun and Oyo States Nigeria. International Journal of Development Strategies in Humanities, Management and Social Sciences, 9(3), 89-128.

lxx. Wales, T. (2013). Organizational sustainability: what is it, and why does it matter? Review of Enterprise and Management Studies, 1(1), 38-49. 